\title{
Construction of English Teaching Mode for Students in Art Colleges --A Study in Perspective of Memetics
}

\author{
Ying $\mathrm{Wu}^{1,}$, Qiao Zhang ${ }^{1}$ \\ ${ }^{1}$ Sichuan University of Media and Communications, Chengdu, Sichuan Province, China \\ awwyy-008@163.com
}

Keywords: memetics, art colleges, English teaching mode.

\begin{abstract}
Due to the special structure of the students in art colleges, proper English teaching methods are expected. In addition, the higher demand of applying English requires more efficient learning. Memetics helps the teachers to establish and improve the teaching mode and to improve the students' learning. This paper introduces the definition of memetics and the application of memetics in English teaching in art colleges. It also explores into the improvement of English teaching mode while adopting memetics and the difficulties during its application.
\end{abstract}

\section{Introduction}

In terms of domestic special situation, the students in art colleges are usually those who are not very well in their studies. Therefore, their performance are poorer compared to those from other colleges and universities and they do not have enough interests in learning English. To solve these problems, domestic schools introduce a number of new teaching methods with an intention to improve the students' learning efficiency. The present study focuses on one of the learning methods, memetics.

\section{Definition of Memetics}

The term, meme, is original from Richard's book titled The Selfish Gene which is published in 1976. He is a biologist and ecologist. In this book, meme is regarded as a phenomenon of gene imitation. This book describes how genes promote their evolution and adapt the surrounding environment through imitation. Literary works introduces meme as the reproduction and dissemination of an idea, which is mainly reflected in expression [1]. Since the introduction of meme in 2003, many scholars in China have led to a wide range of explorations and researches. In 2005, MA Xiao combined meme with language teaching. Chinese people's demand on foreign language is mainly English. Thus, memetics has been aroused much attention, especially in English teaching. And the teaching mode focusing on infection and imitation has achieved great success.

\section{Applications of Memetics in English Teaching for Students in Art Colleges}

Assimilation. Assimilation mainly refers to the infection and homology between the hosts. In English teaching, both teachers and students are the hosts and knowledge is the effective memes. With teachers' instruction, the effective memes are spread among the host of students. Finally, host synchronization would occur. The students would gain the same knowledge as the teachers do. In daily teaching, this is achieved through a continuous manner. While receiving the teachers' instruction, the students can absorb some valuable knowledge, and gradually assimilate it in the process of consolidation. For example, while teaching the concept of time, the teachers can list some quotes, "Time is money", "Time and tide waits for no man" and so on. What should be noted is the teachers should choose concise sentences and closely related to realities. These simple sentences would give the students a clear understanding. Thus, they would profoundly understand the meaning of the words with a more practical way. The resonance between teachers and students would 
gradually enrich the students' vocabulary, deepen their understanding of the sentence structure of another language and gradually improve the students' English proficiency and their writing skills.

For instance, in these two sentences, "People from different backgrounds hold different attitudes towards the issue" and "It is quite understandable that views on this issue vary from person to person", although the vocabularies are different, they have the same meaning. This is due to assimilation.

Memory. After accepting memes, the student would convert them into fixed memory which is vulnerable memes. These would be gradually forgotten by the students. The students' memory can be divided into short-term memory and long-term memory. Short-term memory is fast and it is easy to be disordered and fuzzy. It is mechanically memorized and lacks understanding, which is not suitable for language learning. Thus, the students should focus on long-term memory. In perspective of memetics, the students should review and deepen what they have learnt. The process of recall under the construction of memetics contributes to the students' impressions of knowledge [2]. At the same time, during their daily life, the teachers could guide the students to apply and enhance their knowledge with continuous practice. Thus, the students' short-memory can be efficiently converted into long-term memory. Even if the students only make a brief review every once in a while, they are able to apply the knowledge and make their memory a powerful meme which is helpful for learning.

Expression. Expression is to apply students' knowledge after memorizing. Expression is based on memory and they are positively correlated. The students in art school mainly pay attention to English books in high school. Both their written and oral English are weak. After receiving some knowledge, the students would consciously improve their expressive skills. In perspective of memetics, oral practice is the main approach adopted by the teachers to improve the students' expression. Thus, the students should positively apply what they have learned in conversation. The teachers should also create more opportunities for students, and adopt more topics related to their daily life. While expressing, the students could use the quotes stored through assimilation. These sentences and phrases would make their spoken dialogue vivid and valuable. Therefore, the expression depends on the basic situation of students assimilation and memory. If they can remember more effective sentences, they would effectively improve their spoken and written English skills.

Transmission. Being similar to expression which is based on memory, transmission is based on expression. Both expression and transmission are released outwardly memes. The difference is that expression is the students' self-expression of their learning outcomes and learning ability. Essentially, the service object is the person who expresses. However, transmission mainly focuses on the receivers. Thus, the service object is the person who receives information. Meanwhile, transmission has a screening process. The good information would be transmitted from one to another while the bad information might be stopped by someone. Generally, it is a process of natural selection. For instance, a good composition would be a model essay for other students while the poor may not be recognized by people, and finally it would lose its value. Unlike assimilation and memory, transmission is not the behavior changing from the hosts of teachers to the hosts of students, but the exchange among students [3]. Being the last stage of memetics, transmission follows the above three stages and forms a completed cycle. Thereby, the information input would be output.

\section{English Teaching Mode in Art Colleges Constructed by Memetics}

Previewing. Previewing before each lesson is an essential expenditure process. Therefore, the teachers need to use proper strategies to guide the students to complete their preview. In this way, the students would gain some knowledge to improve their English. In their future studies, they can positively complete the task of preview even without the teachers' supervision. There are many approaches for previewing. Among them, the most practical is translation and recitation. In this paper, we focus on recitation. The recitation of preview does not mean they have to recite the full text, but some difficult sentences or those deserve to be stored. Recitation is a way of self-assimilation. During the process of meme assimilation, the students would gradually have a very rich storage of knowledge, which would help to improve their writing skills and long-term memory capacity. This is of great significance for further English teaching. Thus, the teachers could carry out some incentive strategies. For example, reciting and exhibiting quotes by famous people. The students could show the collected 
quotes and share them with others. This not only acknowledges students' usual achievements, but also promotes the exchange and communication among students. Therefore, the students could help each other and learn from each other.

Warming up. Warming up is the production of meme and listening and speaking. It is the first part of the whole class. It is after the students' preview and before the teachers' teaching. An excellent introduction can attract the students' attention in a short time through simple and interesting language. It can also improve their interests in learning and ensure that they would focus on the following study. During the process of warming up, the teachers can use some pictures and videos which are related to the topics and courses. They can also discuss with the students and focus on teaching contents. For example, while exploring into the teachers' profession, the teachers can communicate with the students in English. The students can even ask some questions they are interested in. And the teachers can answer them in English. The teachers' language is a kind of output, as well as a process of assimilation and memory. The students' response and questions is the feedback after input, which includes expression and transmission. The teachers should pay attention to two aspects. Firstly, the spoken sentences must be clear and concise. Complex sentences are not expected. Otherwise, it would exceed the students' response. Secondly, the teachers should control the time of warming up. The students should be quite excited, which would extend the time of warming up and interfere the following courses.

Understanding. Understanding is the students' refinement and presentation after reading. The relationship between meme and reading mainly depends on whether the students use proper methods in right direction while reading. Firstly, the students should have a general overview of the full text within three to five minutes. During this period, the students need to find the key sentences which can show the main idea of the text. In general, the more important sentences are at the beginning of a paragraph and its last sentence. Therefore, the students could pay attention to these two parts, which can also effectively save their time. Secondly, after an overview of the full text, the teachers should quickly review the students' achievements in fast reading. The teachers can choose those who can afford the article difficulty, which would efficiently improve the students' scores. Frequently questioning can not only improve the students' communication skills, but also encourage some students who are not enthusiastic to keep previewing before class. Thirdly, after gaining the general idea of the full text, the students need to read the passage deeply. They are expected to find out the difficult sentences or those with typical structure. This is also what the students should do before class. However, the students may not roughly sum up the general idea before class. They may generate new feelings during the previous interpretation, so the teachers should give the students enough time. Finally, the students should make a self-presentation. For instance, the students could interpret some sentences and analyze the difficult points and syntax. During this period, the teachers need to guide the students to discover and solve problems. Therefore, the students can strengthen what they have learnt and help them convert short-term memory into long-term memory.

Summarizing. Summarizing occurs at the end of the course. The teachers should refine the difficult points and help the students to apply their knowledge. Firstly, the teachers should make a summary of the passage. For the students in art colleges, the teachers should focus on the usage of new words and grammar. In the lower grades, the students should strengthen their basic knowledge. In the higher grades, they should make a clear distinction among the complex sentences, as well as other special examples. Secondly, the students should make a self-summary after class. The sooner, the better [4]. After the teachers' summary, assimilation and memory memes will give the students a deep impression. This period is proper to convert short-term memory into long-term memory. Thus, the students should make the best use of this time. The teachers can also arrange some exercises to strengthen the students' knowledge learned. And the regular new word dictation which aims to examine the students' is also expected. For the students with poor summarizing ability, the teachers could also give them some guidance to help them use the correct methods to summarize. While assessing, the teachers could pay attention to their review and timely solve their confusions. But on the other hand, the teachers should give some chances to the students, so that they would not totally rely on their teachers. For instance, the teachers can ask a few simple questions in class, which helps 
to establish the students' self-confidence, encourage them to actively study and improve interest in English learning.

\section{Conclusions}

Memetics has contributed to biology and linguistics, as well as language teaching. In English teaching in art colleges, the mode of assimilation, memory, expression, and transmission helps the teachers to establish a teaching mode of previewing and warming up, understanding and summarizing. This method is helpful for students to consolidate their knowledge and timely convert short-term memory into long-term memory. In conclusion, memetics is much proper in English teaching for students in art colleges and can be practically used.

\section{Acknowledgement}

Fund Project: This project, Exploration into English Teaching Reform for Students Majoring in Acting, is supported by Foundation for Social Science Researches of Sichuan Provincial Education Department. Project No.: 15TD0040.

\section{References}

[1] CHEN Jun. Construction of Teaching Mode Combining English Teaching and Majors for Students in Art Colleges [J]. Journal of Jilin TV \& Radio University. 2015 (07): 29-31.

[2] ZHOU Yishu. Application of Memetics in English Teaching in Universities [J]. Journal of Tianjin Foreign Studies University. 2015 (03): 84.

[3] HAN Rong \& HU Ronghua. New Ideas of Construction of English Teaching Mode for Students in Art Colleges [J]. Manager' Journal. 2011 (01): 102-104.

[4] ZHANG Mengwei \& MA Huijuan. Inspirations of Memetics on English Reading for Students in Independent Colleges - A Case Study of Qindao College, Qingdao University of Technology [J]. China Training. 2015 (16): 49. 